\title{
The Nutritional Value of Pacific Herring: an Ancient Cultural Keystone Species on the Northwest Coast of North America
}

\author{
Madonna L. Moss ${ }^{\mathrm{a}}$ \\ ${ }^{a}$ Department of Anthropology, University of Oregon, Eugene, OR 97403-1218, USA, \\ mmoss@uoregon.edu
}

*Corresponding author. Tel.: +1 541346 6076; fax: +1 541346 0668. E-mail address: mmoss@uoregon.edu (M.L. Moss)

Keywords: Clupea pallasii, fisheries, EPA, DHA, DPA, Omega-3 Fatty Acids

\begin{abstract}
The perspective of nutritional ecology produces a more comprehensive understanding of the dietary, economic, and socio-cultural importance of Pacific herring (Clupea pallasii) to Northwest Coast societies and Alaska Natives than do models derived from optimal foraging theory. The food value of herring meat, eggs, and oil are found to rank highly not just in calories or protein, but especially in healthy omega-3 fatty acids. Herring provides large amounts of EPA (eicosapentaenoic acid) and DHA (docosahexaenoic acid) in addition to iron, zinc, copper, and selenium. In coastal Alaska and along the Northwest Coast, herring was/is one of a vast array of traditional foods in a diverse diet. Herring apparently played different dietary roles in different cultural settings; in some areas it was a seasonal feast food, while in others its products were processed into forms that could be consumed throughout the annual cycle. Herring provided essential nutrients that affected human health, growth, and development, and likely facilitated demographic expansion. Paired with the indigenous and scientific knowledge of how herring function within North Pacific ecosystems, we can better appreciate the role of herring as a cultural keystone species.
\end{abstract}

\section{Introduction}

The Pacific herring (Clupea pallasii) is a small, oil-rich fish that has been an important food across the entire Northwest Coast of North America, stretching from southern Alaska to northern California. Yet salmon is the fish most often associated with the Northwest Coast, ever since Clark Wissler christened it The Salmon Area (Wissler 1917). More recently, using watershed, ocean, and nearshore characteristics, Augerot (2005) divided the entire area bounded by the North Pacific Ocean into hierarchical levels of Salmon Ecoregions. Although the conservation purpose of these designations is worthy, it focuses attention on one genus (Oncorhynchus) in a way that obscures ecosystemic relationships among species. For example, herring is a key prey of some (O. tshawytcha, $O$. kisutch), but not all salmon species. Many other fish, in addition to seabirds and marine mammals, depend on herring as prey; as a forage fish, herring convert phytoplankton into food energy consumable by dozens of other animals. Herring in the North Pacific (and other forage fish elsewhere in the world) form large schools during their seasonal cycles that serve as concentrated food resources that feed a wide variety of marine predators, including people.

Garibaldi and Turner (2004) defined a cultural keystone species as one that shapes the identity of a people. On the Northwest Coast there are several cultural keystones including salmon and redcedar, but herring is also a cultural keystone species among some Alaska Native societies, as demonstrated by Thornton and Hebert (2014). In the words of Nelson Islander Louise Kanrilak, "herring are very important to us. When we are out of herring, we are out of food" (Barker 1993:73). Alaska Natives have 
clear knowledge of the ecological importance of herring, for example, Harold Martin (Tlingit) related, "[t]hey're [the herring] just so important to the total food chain ... every animal ... in the sea. They feed everything -things that we're depending on" (Thornton and Hebert 2014:1). In some Tlingit towns and villages, herring are still used in $95 \%$ of the households during the spring season (Sitka Tribe of Alaska 2010). Herring is an important feast food and is widely traded and shipped to Tlingit who live in the "lower 48." Because of its ecological role, herring is also a bellwether species; if herring are doing well, then the marine ecosystem is healthy.

Following the reductionist logic of optimal foraging theory, herring might be considered a low-ranked resource because of its relatively small body size compared to salmon, halibut, Pacific cod, and other sizeable fish caught along the Northwest Coast and Alaska. The handling time for herring might also be considered too costly because of the technologies required to obtain, process, and (in some cases) store the fish. The prey choice or optimal diet model would predict that people would first exploit high-ranked resources and that only when these became scarce, or too costly to pursue, would they turn to lowerranked resources. Particularly in zooarchaeological applications of the model, body size is considered a proxy for prey rank, and by this measure, herring would rank low. If herring were low-ranked, one would expect herring to be used only late in pre-contact history of the Northwest Coast, after larger-sized mammals and other fish had been over-exploited. Such is not the case; instead, herring fishing started in the early Holocene (Moss et al. 2011, 2015). Further, Butler and Campbell (2004; Campbell and Butler 2010) could find no evidence that any Northwest Coast fish experienced resource depression or was over-exploited by indigenous peoples in the ancient past. Unfortunately, comparable synthetic data from across coastal Alaska are not yet available.

Adopting a nutritional ecological approach helps us better understand the economic and cultural importance of herring. Nutritional ecology considers the relationship between essential nutrient intake and overall human health in individuals and how this affects larger demographic trends (Hockett and Haws 2003:211). Whereas the historical ecology of Pacific herring is concurrently addressed in another paper (Moss et al. 2015), here I focus on the nutritional value of herring.

\section{Seasonal Use of Herring Meat, Eggs, and Oil}

Herring still play important roles in the diets of Alaska Natives and First Nations of British Columbia. Although contemporary residents of the region still practice many traditional technologies of herring acquisition, processing, preparation, and storage, some techniques described ethnographically have fallen out of use and been replaced by freezing, canning, etc. My occasional use of the past tense in the description that follows, however, should not be interpreted as evidence that these techniques are not practiced today. My intent is to illustrate the wide range of ways herring were used in different places at different times of the year with tools and facilities that would have been available during pre-contact history. I start by describing Tlingit and Haida practices, and then add in some additional techniques from elsewhere in Alaska.

Among the Tlingit and Haida, herring meat was eaten fresh, dried, smoked, or preserved in oil. Fresh herring could be caught almost anytime during the year; their seasonal movements made them more or less available at certain times in certain places. When they spawn in the spring (from March to May in different parts of southeast Alaska), large schools of herring form, attracting an array of predators that could simultaneously be the target of human hunting and fishing. Into summer and fall, "balls of herring" form in response to the feeding of predators (such as salmon, pinnipeds, or whales), and people in canoes often took advantage of these using nets or herring rakes. The locations where herring spawn (or spawned) in the spring are reasonably well-documented, but where herring move during the 
winter is not well-known. Local and Traditional Knowledge-bearers have documented some of these places in southeast Alaska (Thornton et al. 2010a), indicating that substantial numbers of fresh herring can also be obtained in the winter. Whole herring were also caught to be used as bait for other fish.

Herring eggs are collected in the spring. Female herring lay eggs on rocks, seaweeds, eelgrass, and other substrates in the intertidal and subtidal zones, where they are subsequently fertilized by the milt of the male herring. Alaska Native and First Nation collectors often lay out hemlock or cedar boughs on which eggs are laid and can easily be collected. They also operated floating traps. Herring eggs are a culinary delicacy, especially when eaten raw and fresh. The spring egg harvest continues to be an important cultural practice, and herring eggs are cherished as a feast food associated with considerable prestige. Herring eggs (raw or cooked) are often frozen today, and brought out at cultural events throughout the year. Herring eggs traditionally were dried, or could be preserved in oil or fermented. Emmons (1991:147) characterized herring eggs as a "luxury rather than a regular article of diet." We will return to this issue after considering the nutritional value of herring in the following section.

During autumn, the fat content of herring is at its highest level of the annual cycle. Herring rakes and nets were used to gather thousands of herring. Herring oil was traditionally processed like oil of another small fish, eulachon (Thaleichthys pacificus). Old canoes were used as large cooking vessels, into which large quantities of small fish were placed and cooked to render out the oil. The oil was skimmed off the top and placed in seal bladders or boxes for long-term storage. Emmons (1991) described the circumstance, "[a]s the fish was kept too long (...by white standards, not by those of the natives), the oil was very rancid and offensive to us, but was doubly appreciated by them." This fermented oil might fall among the "tastily rotten," foods described by Yamin Pasternak et al. (2014). Such fermentation apparently facilitated long-term preservation; without it, the oil would spoil (Emmons 1991:148; Mintz 2014:640).

Other Alaska Native groups, including the Yupik and Inupiat, store fermented fish (including herring) in seal pokes (sealskin bags) that are then put into water-filled pits or holes dug into permafrost to stabilize the temperature (Frink and Giordano, this volume; Starks 2011). Dried herring can also be stored in seal pokes. I note that fermented herring is a staple of Scandinavian cuisines and fermented garum (fish sauce) was a staple in the Mediterranean 2000 years ago. Fermentation can actually enhance the nutritional value of a food because the resulting lactic acid bacteria improve digestibility (Gilliland 1990).

\section{Results: The Nutritional Value of Herring}

The nutritional value of herring is first considered vis à vis other traditional Northwest Coast animal foods. The nutrients present in an array of traditional Tlingit foods are taken from data compiled in Newton and Moss (1984; Table 1). Figure 1 illustrates the number of calories per $100 \mathrm{~g}$ portion of a food. Eulachon is the richest at 308 calories per $100 \mathrm{~g}$, followed by dried herring roe at 294 calories, and herring meat at 270 calories. These small fish have higher concentrations of calories than do salmon, beaver, seal, deer, and other foods. For protein (Figure 2), dried herring roe ranks at the top, with $60.4 \mathrm{~g}$ per $100 \mathrm{~g}$, followed by herring flesh at $45.7 \mathrm{~g}$. Herring roe on kelp falls at the bottom, partly because the kelp takes up some of the $100 \mathrm{~g}$. With regard to fat (Figure 3), eulachon has $24.8 \mathrm{~g}$ of fat per $100 \mathrm{~g}$, over twice that of herring meat, which ranks second. Bear, salmon, and herring roe are all leaner than herring and eulachon meat. As is widely known, some fats are healthier than others, and herring is very rich in omega-3 fatty acids (Table 2, with data from OSU Seafood Network Information Center 2014). Of the ranked animal foods, herring yield $1.0 \mathrm{~g}$ of EPA per $100 \mathrm{~g}$ of edible tissue, the most of any taxa listed. Compared to spiny dogfish (Squalus acanthias; $1.2 \mathrm{~g} / 100 \mathrm{~g}$ ), herring has the second highest amount of 
DHA (0.7 g/100 g). Spiny dogfish is an interesting resource because it commonly occurs in Northwest Coast archaeological assemblages, but only in low abundance. ${ }^{1}$ Elsewhere in the world, dogfish liver oil was highly valued (Nicholson 2005). Taking EPA and DHA together, herring rank second among the 11 animal foods listed. Unfortunately, eulachon is not listed among this group. Spiny dogfish and herring also yield $0.1 \mathrm{~g} / 100 \mathrm{~g}$ of LNA (alpha-linolenic acid), which humans can convert to EPA and DHA, but not very efficiently. As can be seen in Table 2 , smelt is the richest in LNA, with $0.5 \mathrm{~g} / 100$. USDA (2014) data on EPA and DHA content for a wider range of resources are presented in Figure 4 . Fish roe is ranked at the top, followed by herring. Both EPA and DHA provide important protection from cardiovascular and Alzheimer's diseases. These fatty acids inhibit platelet aggregation and reduce lipids (especially triglycerides) in the blood (Bates et al. 1985:78). They also are essential to healthy brain and vision development of infants and reproductive health of women (Bourre 2006).

Figure 5 illustrates the amount of omega- 3 fatty acids per $100 \mathrm{~g}$ and per meal $(227 \mathrm{~g}$ ) for fish from around the world, with data from Sidhu (2003). The top-ranking sardines at the top of the chart (7.5 $\mathrm{g} / \mathrm{meal}$ ) are packed in sardine oil, so they incorporate added fat. Atlantic mackerel $(5.7 \mathrm{~g} / \mathrm{meal})$ was the only other of the world's fish ranked higher than Pacific herring ( $3.9 \mathrm{~g} / \mathrm{meal})$ with regard to omega-3 fatty acids. All of the top 11 fish provide the minimum daily requirement of omega- 3 fatty acids per meal. Sidhu (2003:341) explains that consuming these omega-3 fatty acids reduces the risk of coronary heart disease, decreases mild hypertension, prevents certain cardiac arrhythmias and sudden death, and lowers the incidence of diabetes. Sidhu (2003:341) adds that omega-3 fatty acids may alleviate some of the symptoms of rheumatoid arthritis.

From data compiled by Shahidi and Miraliakbari (2006) and Shahidi and Senanayake (2006), we can compare the distribution of fatty acids in herring, salmon, and seal oils (Figure 6). Although these data derive from Atlantic species, they are likely applicable to Pacific species. While the spatial distribution of fatty acids in herring and salmon oil is similar, seal oil has three fatty acids (16:1n-7; 18:1n-9 and n-11; 20:1n-9) in substantial quantities not present in the fish oils. Seal oil also has about 10 times the amount of DPA (docosapentaenoic acid, 22:5n-3) than the fish oils and DPA allows for faster and more thorough metabolism of healthful fatty acids (Shahidi and Miraliakbari 2006:228). The common use of seal oil as a condiment in Northwest Coast diets apparently allows consumers to more effectively metabolize healthy fatty acids from fish.

For other micronutrients (Figure 7), we see that herring provides a large amount of iron (1.12 mg/100 g), and respectable amounts of zinc $(0.53 \mathrm{mg} / 100 \mathrm{~g})$ and copper $(0.078 \mathrm{mg} / 100 \mathrm{~g})$. Of the taxa shown here, lingcod provides the most zinc $(1.0 \mathrm{mg} / 100 \mathrm{~g})$ and copper $(0.141 \mathrm{mg} / 100 \mathrm{~g})$. Both herring and lingcod provide more than Chinook salmon. For selenium (Figure 8), herring eggs provide a large quantity (1.07 $\mathrm{mg} / \mathrm{kg})$, over twice that of the second-ranked rockfish $(0.49 \mathrm{mg} / \mathrm{kg}$; Yamashita et al. 2013:390-391). Herring flesh is ranked third, yielding $0.4 \mathrm{mg} / \mathrm{kg}$. Selenium is a constituent of antioxidant enzymes and proteins, and helps form DNA and acts as an antioxidant to prevent cell damage from free radicals (Yamashita et al. 2013).

\footnotetext{
${ }^{1}$ In general, livers of fish and marine mammals are richer in fatty acids than the bodies of these animals (Brown and Heron 2005:68).
} 
Table 1: Macronutrients in Traditional Tlingit Animal Foods per $100 \mathrm{~g}$ Portion (data from Newton and Moss 1984: Table 1).

\begin{tabular}{|l|r|r|r|}
\hline & calories & protein (g) & fat (g) \\
\hline bear & & & \\
\hline beaver & 148 & 19.9 & 8.3 \\
\hline cockles & 150 & 26.8 & 4.8 \\
\hline deer & 79 & 13.5 & 0.7 \\
\hline duck & 126 & 22.9 & 3.4 \\
\hline eulachon & 109 & 21.5 & 2.1 \\
\hline gumboots & 308 & 20.5 & 24.8 \\
\hline herring meat & 83 & 17.1 & 1.6 \\
\hline herring roe - dried & 270 & 45.7 & 10.6 \\
\hline herring on kelp & 294 & 60.4 & 6.6 \\
\hline octopus & 59 & 11.3 & 0.8 \\
\hline salmon, chinook, smoked, canned & 57 & 11.9 & 0.6 \\
\hline salmon, sockeye, kippered & 150 & 23.2 & 5.9 \\
\hline sea cucumber & 190 & 29.5 & 7.7 \\
\hline seal & 68 & 13.0 & 0.4 \\
\hline
\end{tabular}

Table 2: Omega-3 Fatty Acid Content in grams per $100 \mathrm{~g}$ of edible tissue (data from Oregon State University Seafood Network Information Center 2014).

\begin{tabular}{|l|r|r|r|r|r|}
\hline & LNA & EPA & DHA & EPA+DHA & $\begin{array}{c}\text { Total } \\
\text { Omega-3 }\end{array}$ \\
\hline spiny dogfish & 0.1 & 0.7 & 1.2 & 1.9 & 2.0 \\
\hline herring & 0.1 & 1.0 & 0.7 & 1.7 & 1.8 \\
\hline king salmon & 0.1 & 0.8 & 0.6 & 1.4 & 1.5 \\
\hline sockeye salmon & 0.1 & 0.5 & 0.7 & 1.2 & 1.3 \\
\hline capelin & 0.1 & 0.6 & 0.5 & 1.1 & 1.2 \\
\hline pink salmon & & 0.4 & 0.6 & 1.0 & 1.0 \\
\hline smelt & 0.5 & 0.3 & 0.2 & 0.5 & 1.0 \\
\hline pollock & 0.0 & 0.1 & 0.4 & 0.5 & 0.5 \\
\hline halibut & 0.1 & 0.1 & 0.3 & 0.4 & 0.5 \\
\hline crab & 0.0 & 0.3 & 0.1 & 0.4 & 0.4 \\
\hline clam & 0.0 & 0.1 & 0.1 & 0.2 & 0.2 \\
\hline
\end{tabular}




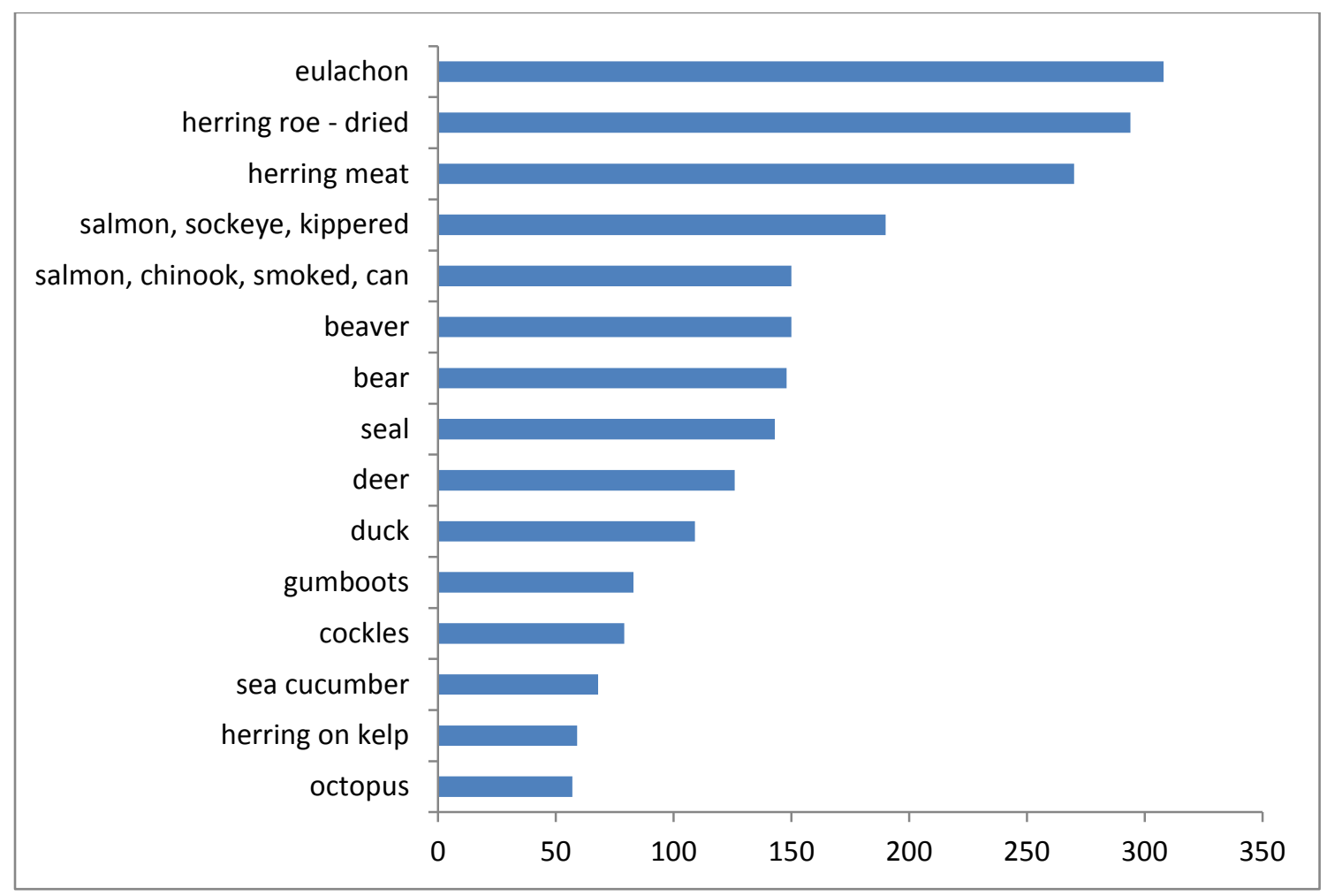

Figure 1: Calories in Traditional Tlingit Animal Foods per $100 \mathrm{~g}$ Portion (data from Newton and Moss 1984: Table 1).

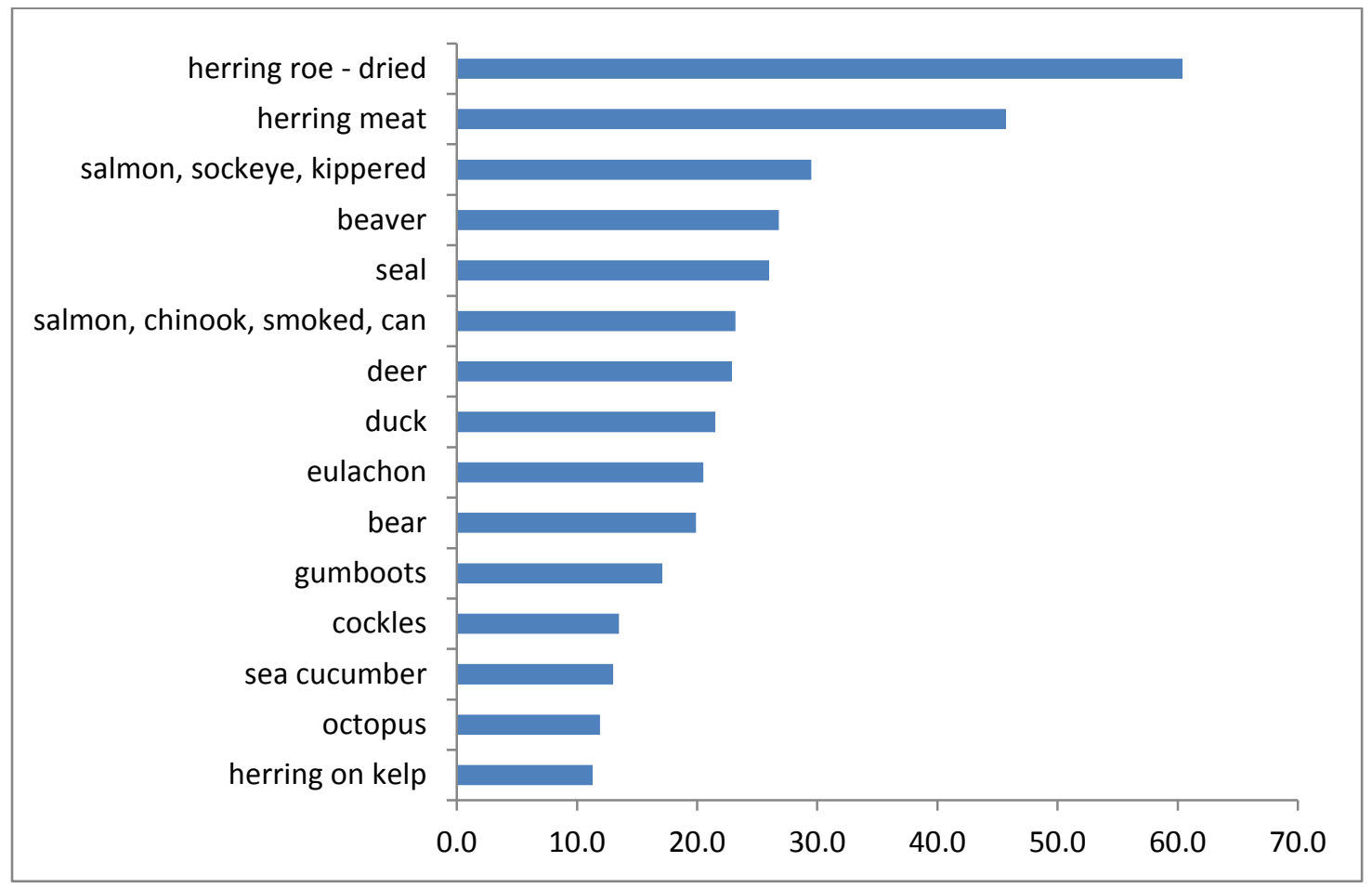

Figure 2: Protein (g) in Traditional Tlingit Animal Foods per $100 \mathrm{~g}$ Portion (data from Newton and Moss 1984: Table 1). 


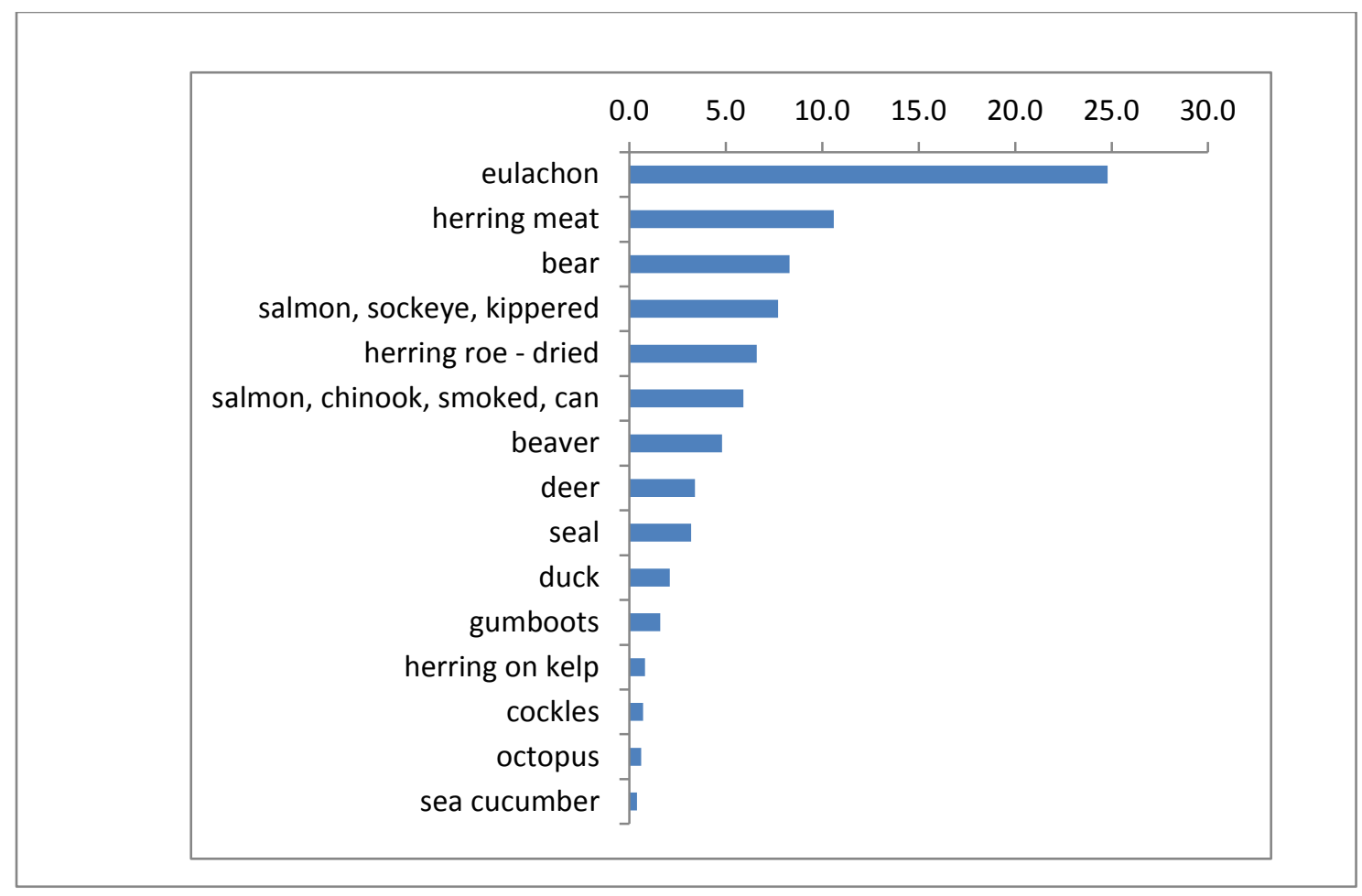

Figure 3: Fat (g) in Traditional Tlingit Animal Foods per $100 \mathrm{~g}$ Portion (data from Newton and Moss 1984: Table 1). 


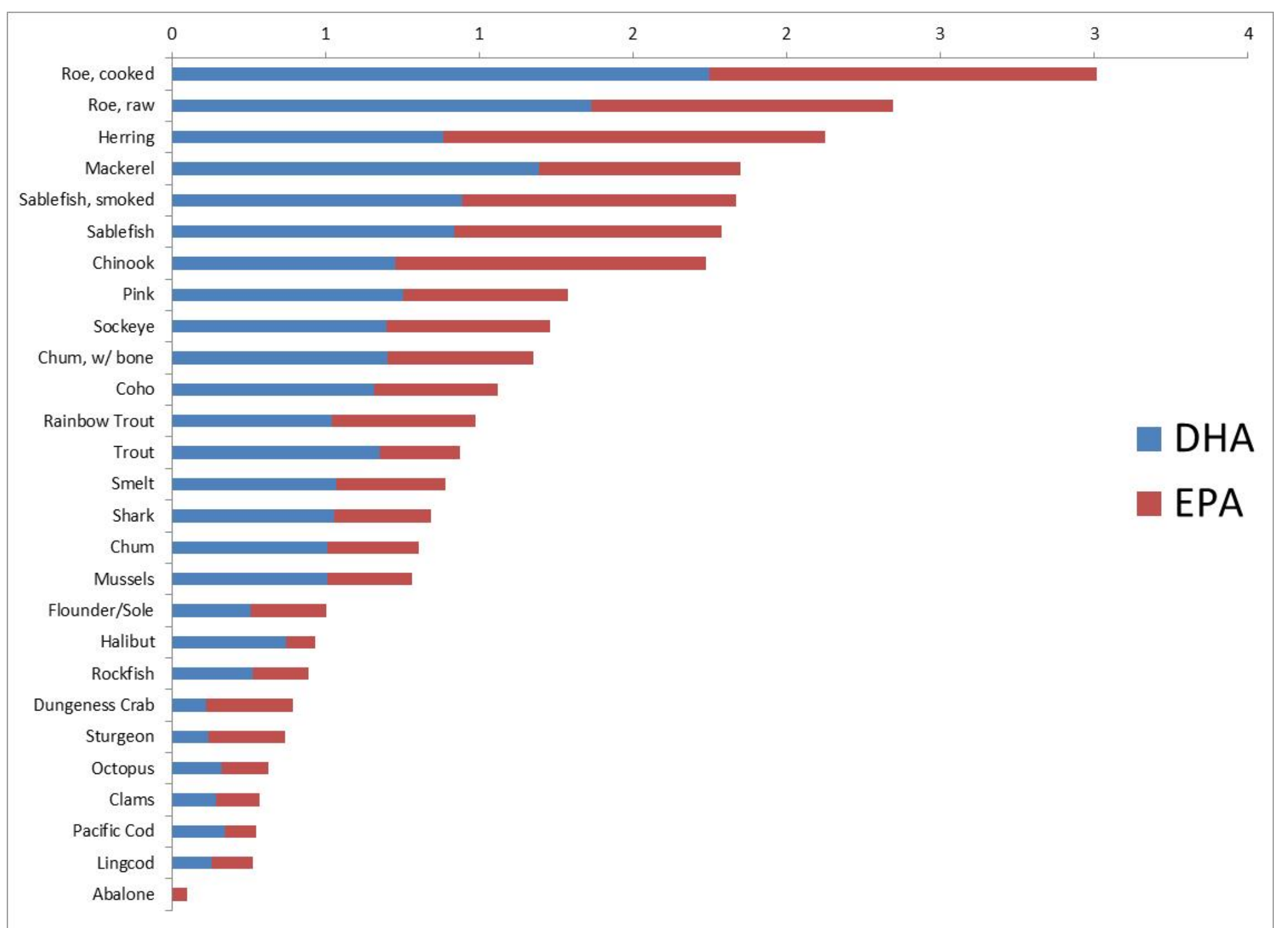

Figure 4: DHA (docosahexaenoic acid) and EPA (eicosapentaenoic acid) Content (g) in $100 \mathrm{~g}$ of Selected Seafoods (data from USDA 2014). 


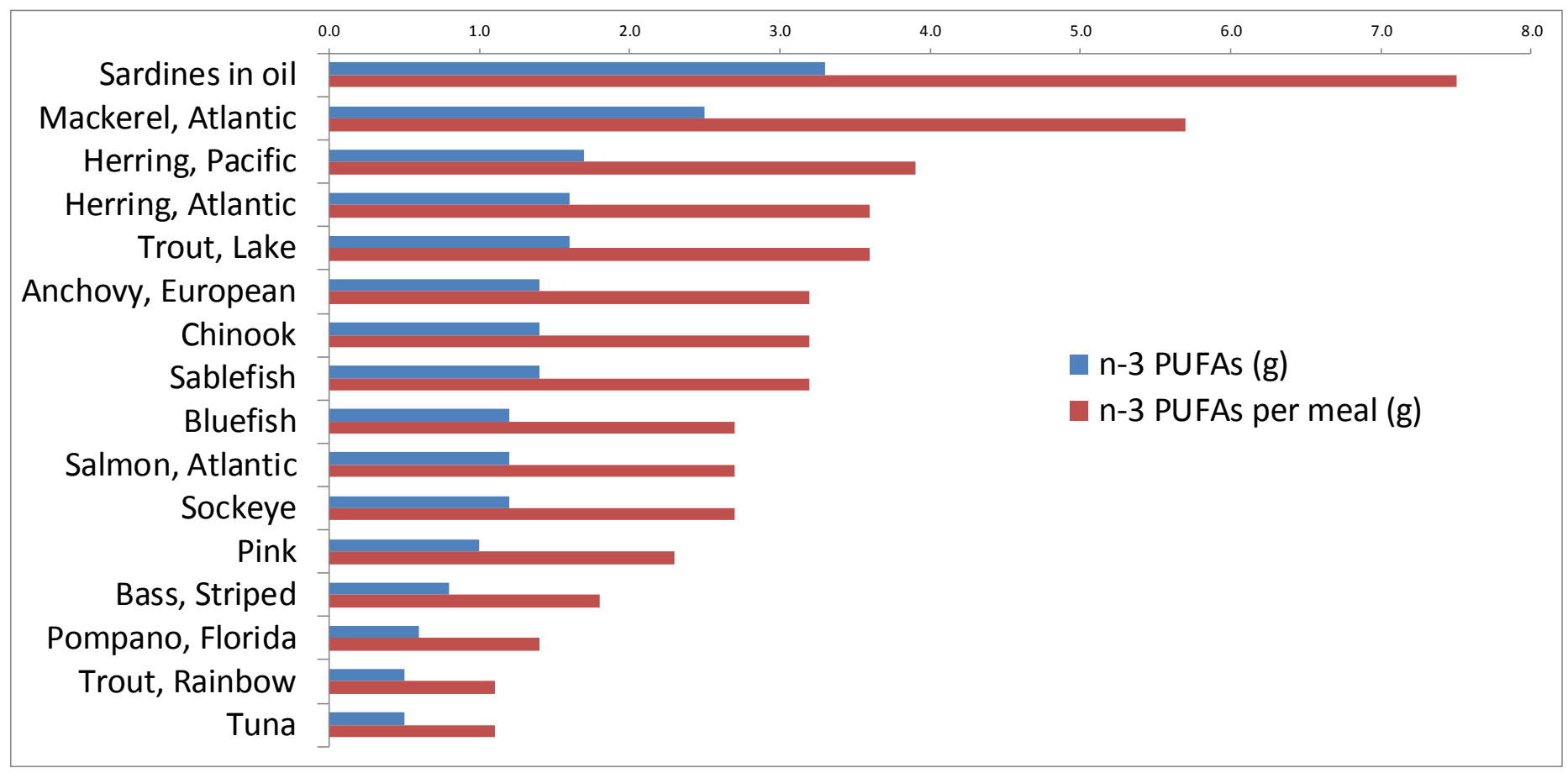

Figure 5: Omega-3 Fatty Acids per $100 \mathrm{~g}$ and per Meal (227 g) for Selected World Fish (Sidhu 2003). 


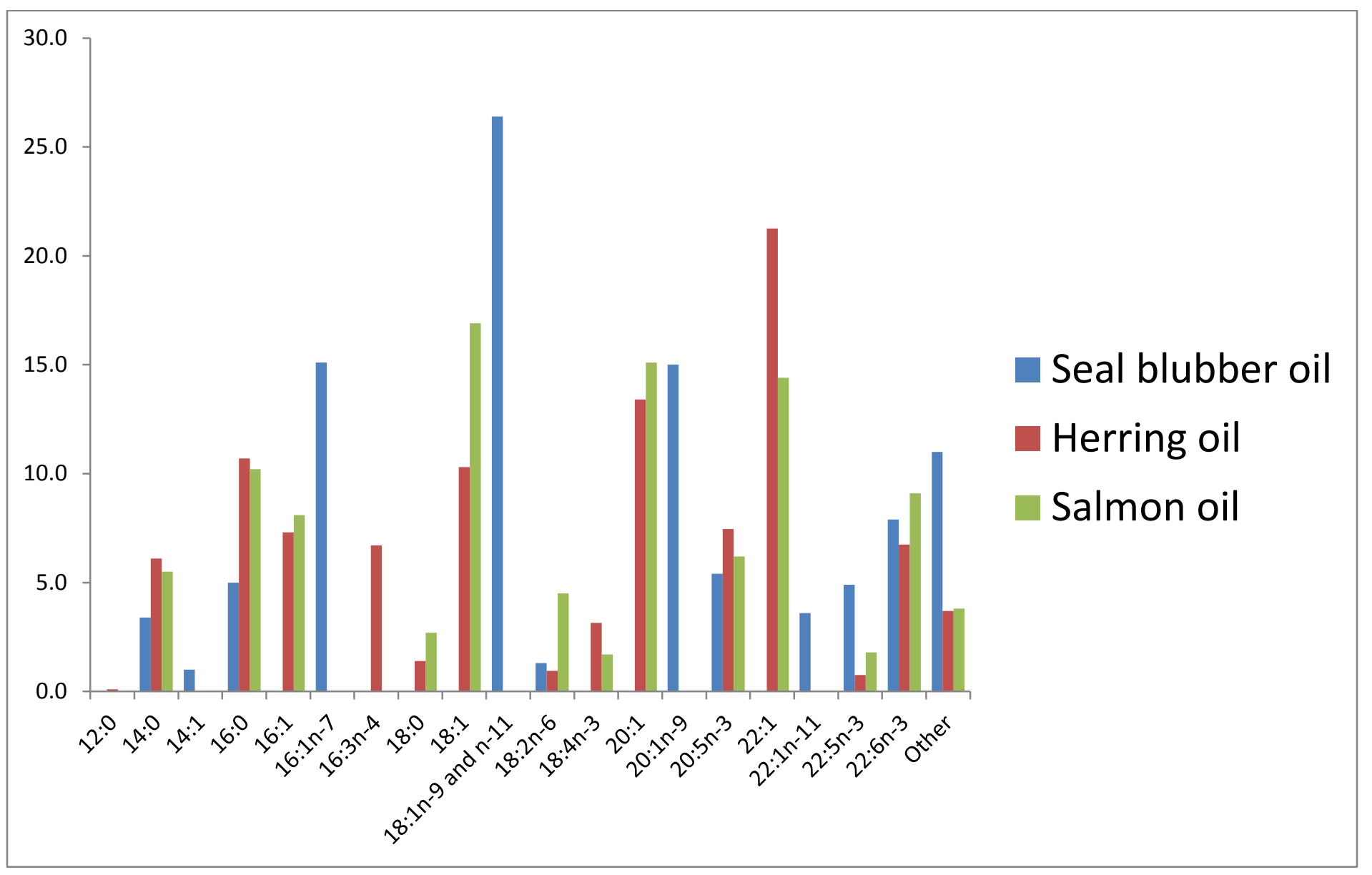

Figure 6: Distribution of Specific Fatty Acids (weight \%) in Seal, Herring, and Salmon Oils (data from Shahidi and Miraliakbari [2006] and Shahidi and Senanayake [2006]). 


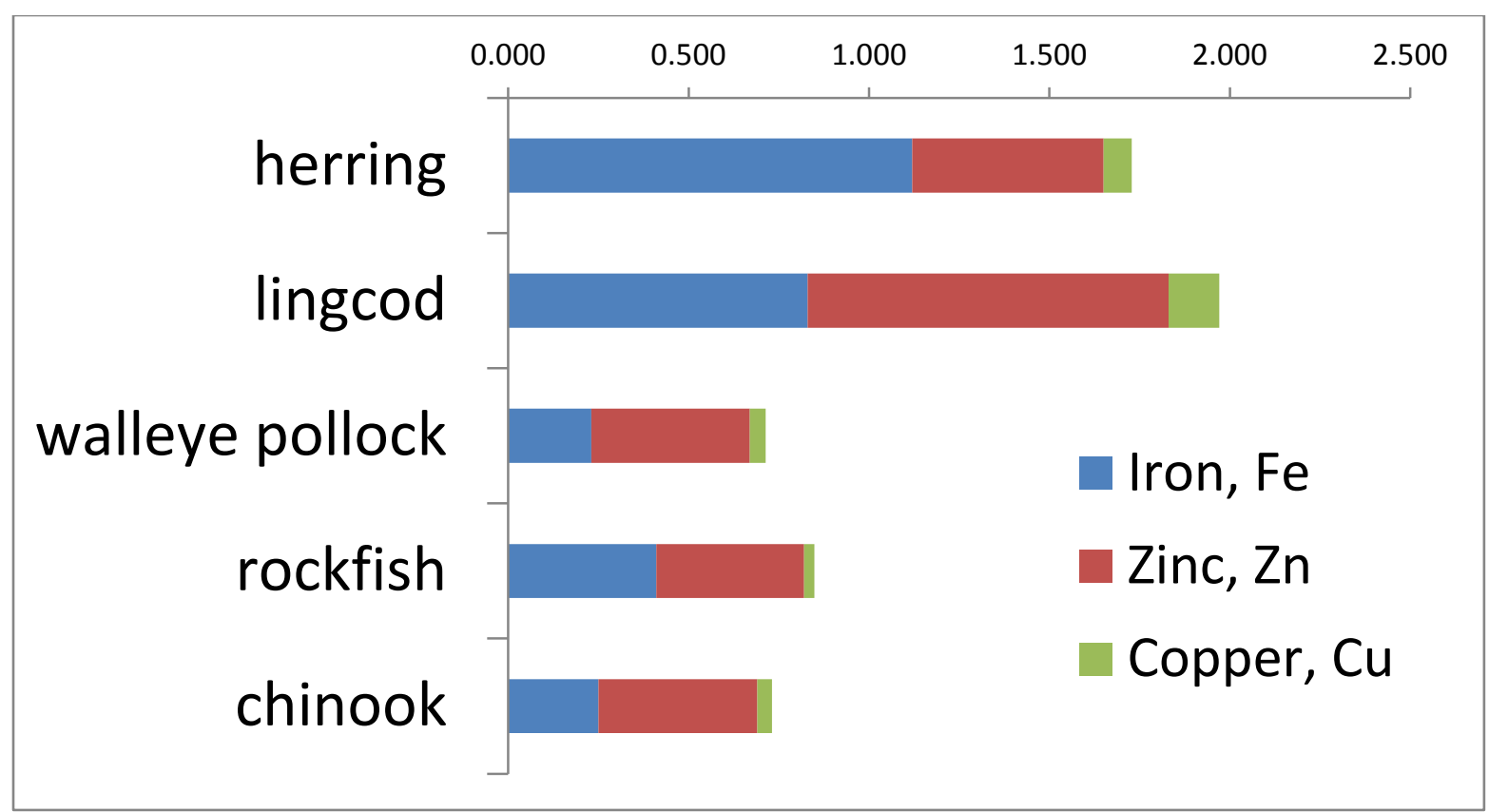

Figure 7: Micronutrients (mg) of Five North Pacific Fish (data from Titi Tudorancea Bulletin 2015).

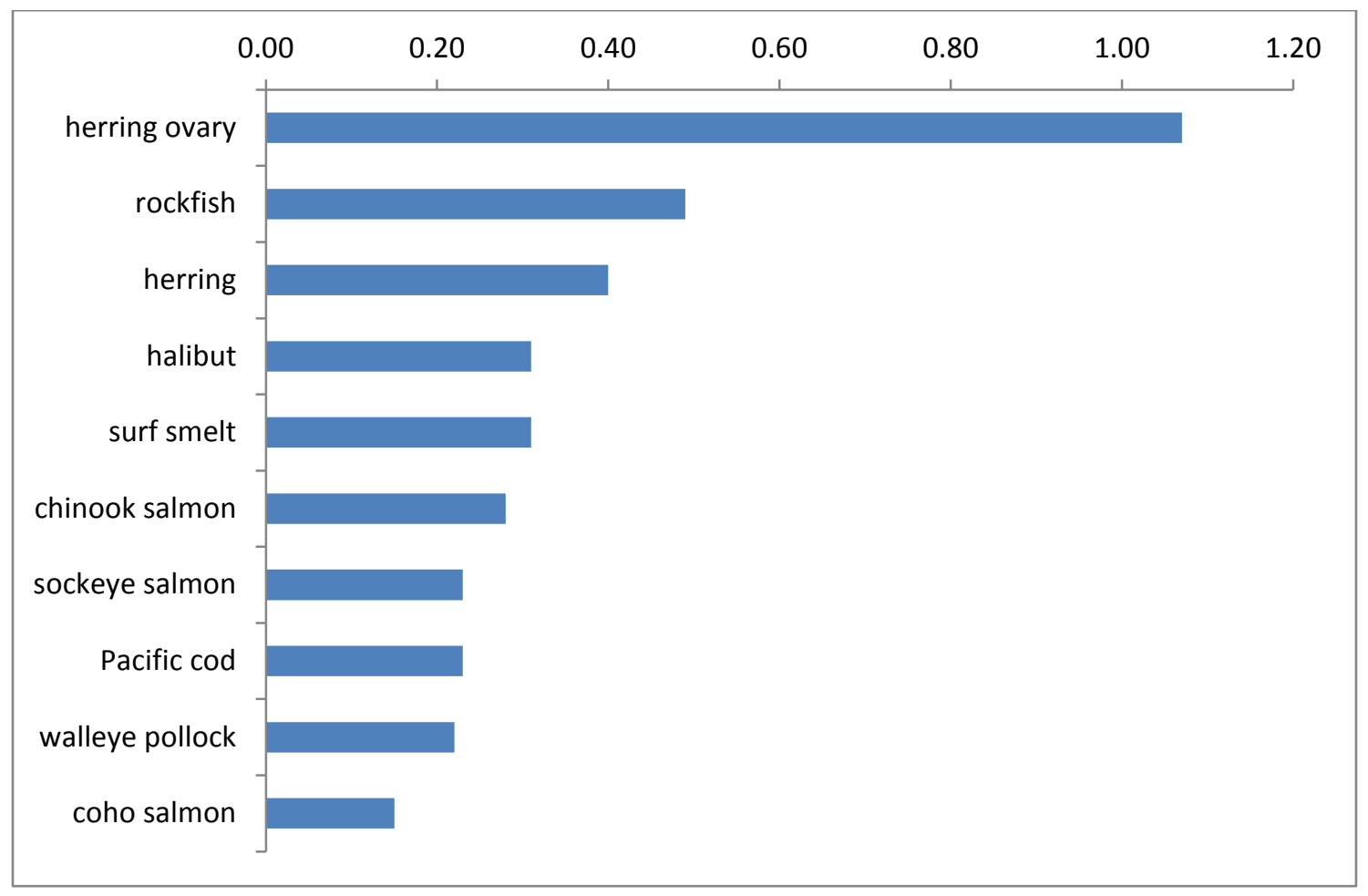

Figure 8: Selenium Content (mg) of North Pacific Fish (data from Yamashita et al. 2013). 


\section{The Role of Herring in Alaska Native Diets}

Was herring a staple food among Northwest Coast societies and Alaska Natives? What role did herring play in a diet where animal foods are abundant and abundantly rich in protein, fat, and minerals? Some common ideas are that a staple food should fulfill most energy and nutrient needs, be a dietary mainstay, commonly consumed, consumed year round, or provide the bulk of calories consumed (Douglas 1997). In the food security and development policy literature, staple foods are conceived of as having to be cheap and supply plenty of starch (e.g., United Nations 2000:1).

In the previous section, we have seen that herring products are rich enough food sources that they could supply the calories, protein, healthy fats, iron, copper, zinc and selenium to be a dietary mainstay. Herring roe is particularly nutritious, including over half the daily requirement of thiamin (First Nations Health Council n.d.). But how much herring roe was consumed? Was it eaten mostly in the spring when fresh? Did people store large quantities and eat herring eggs throughout the year? Did they eat fresh, dried, or smoked herring and herring oil every day? How we might answer these specific questions archaeologically is yet to be determined.

Looking at zooarchaeological data derived from more than 435,000 fish bones, McKechnie et al. (2014) found herring to be ubiquitous in assemblages across the Northwest Coast. Among the 171 assemblages that used adequate recovery methods, herring was the most abundant fish in 95 assemblages, and the second-most abundant fish in another 41 assemblages. This is a striking result in a culture area where salmon have been considered the most important fish (Moss and Cannon 2011). But these data are too coarse to tell us about the seasonal use of herring and the frequency of its consumption during the annual cycle among different societies.

Today, among the Tlingit of southeast Alaska, herring eggs are a feast food served at cultural events in the spring and throughout the year. Herring eggs are collected en masse in Sitka. Across southeast Alaska's smaller towns, some families are still able to collect small quantities of herring eggs for limited family use. In Sitka, some individual families and the Sitka Tribe of Alaska collect enough to freeze, and frozen herring eggs are brought out for special occasions and shipped to family and friends out-of-state. Collecting herring eggs in the spring is an important cultural practice for Tlingit people, where Haa atxaayi Haa Kusteeyix Sitee, "our food is our Tlingit way of life" helps explain the elemental importance of wild food harvesting and preparation to Tlingit identity (Moss 2010; Newton and Moss 2005). But in the absence of freezing, were herring eggs collected as surplus and widely traded? Even if archaeologists had access to well-sampled collections from mortuary contexts, isotopic study of human remains would not allow the discrimination of all the specific sources of marine foods. Similarly, we do not know if dried herring or herring oil were consumed routinely during the year.

We do know that traditional diets on the Northwest Coast were incredibly diverse. For example, Kopperl and Lape (n.d.) identified almost 300 plant and animal foods as components of traditional Coast Salish diets. Turner (1975) documented over 100 traditionally used plants by coastal First Nations of B.C. With regard to terrestrial plants, diets in Alaska were not as diverse as those of indigenous peoples further south. For example, Alaska is too far north to have the starchy acorns, camas, wapato, biscuitroot, and hazelnut available in Oregon, Washington, and southern British Columbia.

In general, the diets of coastal Alaska Natives were very rich in proteins and fats because of the economic reliance on fish and marine mammals throughout the year. The dietary sources of carbohydrates, however, were limited to berries, roots, seaweeds, and (where available) the inner bark 
of conifer trees. These sources of carbohydrates could, however, be dried or covered in oil for long-term storage. Dried seaweeds were especially good sources of carbohydrates (Newton and Moss 1984:43). Like berries, stems and shoots of green vegetables provided vitamin $\mathrm{C}$ and folic acid, as well as other vitamins and minerals, but unlike berries, stems and shoots did not provide much in the way of carbohydrates (Kuhnlein and Turner 1991:10-11). Small amounts of carbohydrates are found in animal foods, including shellfish, and could have been supplemented by fermented foods (Hui 1985) and occasional gastrophagy (Buck et al., this volume).

There would appear to have been a low risk of protein poisoning ("rabbit starvation") from the excess consumption of lean meat (e.g., Noli and Avery 1988), because so many of the marine foods consumed by Alaska Natives, including seals, had substantial quantities of fat. Protein toxicity can occur if a person's liver or kidneys cannot eliminate potentially toxic wastes generated from protein metabolism (Bilsborough and Mann 2006), but as we have seen, the DPA in seal oil actually facilitates more thorough metabolism of healthful fatty acids in fish. Bates et al. (1985) suggest there is a genetic component to fat metabolism among Northwest Coast groups, and it seems likely that contemporary standards for upper limits to daily protein intake cannot be projected onto the past. As Speth (2010:85) explains, the human body is capable of adapting to changes in consumption by upregulating the enzymes involved in protein metabolism and urea synthesis. M. J. Mosher (this volume) is investigating epigenetic mechanisms to better understand such variation in human metabolism. It does seem likely that at least during some seasons of the year, Alaska Natives would rely on fats rather than carbohydrates to help supply their energy needs.

Clearly the dietary roles played by herring and its by-products require further investigation. For some Alaska Natives such as Nelson Islanders, herring may have served as a dietary mainstay. As quoted previously, Louise Kanrilak stated, "[w]hen we are out of herring, we are out of food" (Barker 1993:73). Perhaps in some areas in some periods of pre-contact history, herring eggs were a seasonal delicacy or luxury food. Because herring spawning in the spring is such a conspicuous and dramatic seasonal event, attracting a wide range of herring predators, it seems likely that people would take advantage of such abundance, particularly after a long dark winter. They would not only collect herring eggs and fish for herring, but they would take some of the other fish, birds, and mammals that prey upon herring (Monks' [1987] "prey as bait" hypothesis). Historical descriptions of schools of herring filling Chatham Strait "for miles," and the reduction oil fishery that operated between July and January testify to the historical abundance of herring in the summer, throughout the fall, and into winter (U.S. Census 1890:51). Such abundance and ubiquity is indicated archaeologically (McKechnie et al. 2014; Moss et al. 2011) and in the oral historical interviews conducted by Thornton (Thornton et al. 2010a 2010b; Thornton and Hebert 2014).

\section{Conclusion}

Herring is just one of an array of foods in traditional Northwest Coast and Alaska Native diets that likely facilitated demographic expansion over hundreds of years. Although traditional Alaska Native diets may have lacked sources of fresh starchy carbohydrates year-round, people's energy needs were well-served by diets high in proteins and healthy fats. The mechanisms by which Alaska Natives metabolized these proteins and fats in ancient times likely differed from how these foods are metabolized by contemporary populations. Certainly, more research into the techniques and technologies of food preparation, processing, storage, and culinary traditions, like that of Yamin Pasternak et al. (2014) and Frink and Giordano (this volume) would go a long way to understanding the survival and resilience of these populations. 
Acknowledgements - I am grateful to Bryan Hockett for organizing the nutritional ecology symposium held at the $80^{\text {th }}$ annual meeting of the Society for American Archaeology, April 15-19, 2015, in San Francisco. The research presented by all the other participants was especially stimulating. I acknowledge my on-going intellectual debt to Virginia Butler who continues to push our field forward. The research reported here is an offshoot of the study of the ancient DNA of Alaska herring that Dongya Yang, Antonia Rodrigues, and Camilla Speller and I are conducting. For that research, we acknowledge the support of NSF Grant 1203868.

\section{References}

Augerot, X. 2005. Atlas of Pacific Salmon. University of California Press, Berkeley, and Wild Salmon Center and Ecotrust, Portland, OR.

Barker, James H. 1993. Always Getting Ready Upterrlainarluta: Yup'ik Eskimo Subsistence in Southwest Alaska. University of Washington Press, Seattle.

Bates, C., C. van Dam, D. F. Horrobin, N. Morse, Y.-S. Huang and M. S. Manku 1985 Plasma Essential Fatty Acids in Pure and Mixed Race American Indians on and off a Diet Exceptionally Rich in Salmon. Prostaglandins Leukotrienes and Medicine 17:77-84.

Bilsborough, S. and N. Mann 2006. A Review of Issues of Dietary Protein Intake in Humans. International Journal of Sport Nutrition and Exercise Metabolism 16(2):129-152.

Bourre, J. M. 2006. Effects of Nutrients (in Food) on the Structure and Function of the Nervous System: Update on Dietary Requirements for Brain. Part 2: Macronutrients. Journal of Nutrition, Health, and Aging 10(5):386-399.

Brown, Louise D. and Carl Heron 2005. Presence or Absence: a Preliminary Study into the Detection of Fish Oils in Ceramics. In The Zooarchaeology of Fats, Oils, Milk and Dairying, edited by J. Mulville and A.K. Outram, pp. 67-76. Oxbow Books, Oxford.

Butler, Virginia L. and Sarah K. Campbell 2004. Resource Intensification and Resource Depression in the Pacific Northwest of North America: a Zooarchaeological Review. Journal of World Prehistory 18:327405.

Campbell, Sarah K. and Virginia L. Butler 2010. Archaeological Evidence for Resilience of Pacific Northwest Salmon Populations and the Socioecological System Over the Last 7500 Years. Ecology and Society 15(1):17. Online document, http://www.ecologyandsociety.org/vol15/iss1/art17/, accessed March 31, 2010.

Douglas, Mary 1997. Deciphering a Meal. In Food and Culture: a Reader, edited by C. Counihan \& P. V. Esterik, pp. 135-158. Routledge, New York and London.

Emmons, George T. 1991. The Tlingit Indians. Frederica de Laguna, ed. University of Washington Press, Seattle; Douglas and McIntyre, Vancouver; American Museum of Natural History, New York.

First Nations Health Council. n.d. Fish. Online document, http://www.fnhc.ca/pdf/Traditional Food Facts Sheets.pdf, accessed April 10, 2015. 
Garibaldi, Ann and Nancy J. Turner 2004. Cultural Keystone Species: Implications for Ecological Conservation and Restoration. Ecology and Society 9(3):1. Online, http://www.ecologyandsociety.org/vol9/iss3/art1.

Gilliland, Stanley E. 1990. Health and Nutritional Benefits from Lactic Acid Bacteria. FEMS Microbiology Reviews 7(1-2):175-188. DOI: http://dx.doi.org/10.1111/j.1574-6968.1990.tb04887.x

Hockett, Bryan and Jonathan Haws 2003 Nutritional Ecology and Diachronic Trends in Paleolithic Diet and Health. Evolutionary Anthropology 12:211-216.

Hui, Yiu H. 1985. Principles and Issues in Nutrition. Wadsworth Health Sciences Division, Monterey, CA.

Kopperl, Robert and Peter Lape n.d. Traditional Coast Salish Foods. Online document, http://www.burkemuseum.org/pub/reviving traditional food knowledge.pdf, accessed April 10, 2015.

Kuhnlein, Harriet V. and Nancy J. Turner 1991. Traditional Plant Foods of the Canadian Indigenous Peoples: Nutrition, Botany and Use. Food and Nutrition in History and Anthropology vol. 8. Gordon and Breach, Philadelphia.

McKechnie, I., D. Lepofsky, M. L. Moss, V. L. Butler, T. J. Orchard, G. Coupland, F. Foster, M. Caldwell, and K. Lertzman 2014. Archaeological Data Provide Alternative Hypotheses on Pacific Herring (Clupea pallasii) Distribution, Abundance, and Variability. PNAS, doi: 10. 1073/pnas. 1316072111. Online February 18, 2014.

Mintz, Sidney W. 2014. Comment on The Rotten Renaissance in the Bering Strait: Loving, Loathing, and Washing the Smell of Foods with a (Re)acquired Taste. Current Anthropology 55(5):639-640.

Monks, Gregory G. 1987. Prey as Bait: the Deep Bay Example. Canadian Journal of Archaeology 11:119142.

Moss, Madonna L. 2010 Re-Thinking Subsistence in Southeast Alaska: the Potential of Zooarchaeology. Alaska Journal of Anthropology 8(1):121-135.

Moss, Madonna L., Virginia L. Butler, and J. Tait Elder 2011. Herring Bones in Southeast Alaska Archaeological Sites: the Record of Tlingit Use of Yaaw (Pacific Herring, Clupea pallasii). In The Archaeology of North Pacific Fisheries, edited by M. L. Moss and A. Cannon. pp. 283-291. University of Alaska Press, Fairbanks.

Moss, Madonna L. and Aubrey Cannon 2011. The Archaeology of North Pacific Fisheries. University of Alaska Press, Fairbanks.

Moss, Madonna L., Antonia Rodrigues, Camilla F. Speller, and Dongya Y. Yang 2015. The Historical Ecology of Pacific Herring: Tracing Alaska Native Use of a Forage Fish. Journal of Archaeological Science Reports, Special Issue, Ichthyoarchaeology in the Americas, submitted May 17, 2015.

Newton, Richard G., and Madonna L. Moss. 1984 The Subsistence Lifeway of the Tlingit People: Excerpts of Oral Interviews. USDA Forest Service, Alaska Region, R10-MR-30, Juneau. 
Newton, Richard G., and Madonna L. Moss. 2005. Haa Atxaayi Haa Kusteeyix Sitee, Our Food is Our Tlingit Way of Life: Excerpts of Oral Interviews. USDA Forest Service, Alaska Region, R10-MR-30, Juneau.

Nicholson, Rebecca A. 2005. Oil from Troubled Waters: Historical and Archaeological Investigations into the use of Fish and Sea Mammal Oil in the Northern Isles of Scotland. In The Zooarchaeology of Fats, Oils, Milk and Dairying, edited by J. Mulville and A.K. Outram, pp. 142-147. Oxbow Books, Oxford.

Noli, Dieter and Graham Avery 1988. Protein Poisoning and Coastal Subsistence. Journal of Archaeological Science 15(4): 395-401.

Oregon State University Seafood Network Information Center 2014. Online document, http://seafood.oregonstate.edu/.pdf\%20Links/Omega-3\%20Content\%20in\%20Fish.pdf, accessed August 25, 2014.

Shahidi, Fereidoon and H. Miraliakbari 2006. Marine Oils: Compositional Characteristics and Health Effects. In Nutraceutical and Specialty Lipids and their Co-products, edited by Fereidoon Shahidi, pp. 227250. Taylor \& Francis, Boca Raton, FL.

Shahidi, Fereidoon and S.P.J.N. Senanayake 2006. Nutraceutical and Specialty Lipids. In Nutraceutical and Specialty Lipids and their Co-products, edited by Fereidoon Shahidi, pp. 2-22. Taylor \& Francis, Boca Raton, FL.

Sidhu, Kirpal S. 2003. Health Benefits and Potential Risks Related to Consumption of Fish or Fish Oil. Regulatory Toxicology and Pharmacology 38:336-344.

Sitka Tribe of Alaska 2010. Annual Report on Management of Customary and Traditional Herring Harvest. Sitka Tribe of Alaska, Sitka.

Speth, John D. 2010. The Paleoanthropology and Archaeology of Big-Game Hunting: Protein, Fat, or Politics? Interdisciplinary Contributions to Archaeology. Springer, New York.

Starks, Zona Spray 2011. Drying and Fermenting in the Arctic: Dictating Women's Roles in Alaska's Inupiat Culture. In Cured, Fermented, and Smoked Foods: Proceedings of the Oxford Symposium on Food and Cookery 2010, edited by Helen Saberi, pp. 302-311. Prospect Books, Totnes, England.

Thornton, Thomas F. and Jamie Hebert 2014 Neoliberal and Neo-Communal Herring Fisheries in Southeast Alaska: Reframing Sustainability in Marine Ecosystems. Marine Policy http://dx.doi.org/10.1016/j.marpol.2014.11.015i

Thornton, Thomas, Virginia Butler, Fritz Funk, Madonna Moss, Jamie Hebert, and J. Tait Elder 2010a Herring Synthesis: Documenting and Modeling Herring Spawning Areas within Socio-Ecological Systems Over Time in the Southeastern Gulf of Alaska. North Pacific Research Board Project \#728. Electronic document, http://herringsynthesis.research.pdx.edu/.

Thornton, Thomas F., Madonna L. Moss, Virginia Butler, Jamie Hebert, and Fritz Funk 2010b. Local and Traditional Knowledge and the Historical Ecology of Pacific Herring in Alaska. Journal of Ecological Anthropology 14(1):81-88. 
Titi Tudorancea Bulletin 2015. Online searches, performed from:

http://www.tititudorancea.com/z/nutrition.htm, accessed March 30, 2015.

Turner, Nancy J. 1975. Food Plants of British Columbia Indians. Part I. Coastal Peoples. B.C. Provincial Museum Handbooks No. 34. Victoria, B.C.

United Nations 2000. Food Insecurity: When People Live with Hunger and Fear Starvation. Food and Agriculture Organization of the United Nations, Viale delle Terme di Caracalla, 00100 Rome, Italy. Online document, http://www.fao.org/docrep/x8200e/x8200e03.htm, accessed May 29, 2015.

U.S. Census Office 1890. Report on Population and Resources of Alaska at the Eleventh Census, 1890. U.S. Government Printing Office, Washington.

USDA 2014 Dietary Guidelines. Appendix G2: Original Food Guide Pyramid Patterns and Description of USDA Analyses. Online document, <http://www.health.gov/dietaryguidelines/dga2005/report/html/table_g2_adda2.htm>, accessed August 25, 2014.

Wissler, Clark 1917. The American Indian: an Introduction to the Anthropology of the New World. Douglas C. McMurtrie, New York.

Yamashita, Yumiko, Michiaki Yamashita, and Haruka lida 2013. Selenium Content in Seafood in Japan. Nutrients 5:388-395, doi:10.3390/nu5020388.

Yamin-Pasternak, Sveta, Andrew Kliskey, Lilian Alessa, Igor Pasternak, and Peter Schweitzer 2014. The Rotten Renaissance in the Bering Strait: Loving, Loathing, and Washing the Smell of Foods with a (Re)acquired Taste. Current Anthropology 55(5):619-646. 